\title{
Variability of ray anatomy of Larix gmelinii along a forest productivity gradient in Siberia
}

\author{
Patrick Fonti ${ }^{1} \cdot$ Maria A. Tabakova ${ }^{2,3} \cdot$ Alexander V. Kirdyanov $^{2} \cdot$ \\ Marina V. Bryukhanova ${ }^{2} \cdot$ Georg von Arx ${ }^{1}$
}

Received: 24 November 2014/Revised: 26 January 2015/ Accepted: 1 April 2015/Published online: 11 April 2015

(C) Springer-Verlag Berlin Heidelberg 2015

\begin{abstract}
Key message This study provides new data and an alternative framework to the debate of tree carbon economy in a context of increasing stress.

Abstract For long-living trees, the resilience in times of stress is directly linked to the amount of accessible reserves. Despite the simplicity of this principle, the understanding of how carbon reserves limit growth and/or induce mortality under global change is still debated. In this study, we quantify how anatomical properties of rays-one of the main container for carbon reserves in tree stems-vary among sites, individuals, and annual rings of Larix gmelinii growing in contrasting sites in Siberia to verify if (1) the ray proportion and anatomical structure is linked to the environment, and/or (2) to changes in other wood tissues. Our observations have highlighted that ray proportion mainly varies among individuals, but little among sites and consecutive annual rings. We also observed that ray size and density scale to the wood structure with a relatively constant ratio of $\sim 2.5$ rays per tracheid, independent of site conditions. These results suggest that the functional connection between the anatomy of rays and tracheid is unaffected by environment and highlight the importance of
\end{abstract}

Communicated by J. Lin.

Patrick Fonti

patrick.fonti@wsl.ch

1 Swiss Federal Institute for Forest, Snow and Landscape Research WSL, Zürcherstr 111, 8903 Birmensdorf, Switzerland

2 V.N. Sukachev Institute of Forest SB RAS, Akademgorodok 50, bld. 28, 660036 Krasnoyarsk, Russia

3 Siberian Federal University, Svobodny av. 79, 660041 Krasnoyarsk, Russia considering allometric relations in ecological comparisons. Comparative studies of long-term trajectory of ray proportion of living and dead trees might unravel observed variability among individuals validating the link between long-term depleted reserves and mortality.

Keywords Tree ring - Tree-ring anatomy - Rays . Ray density · Ray height · Ray volume · Forest decline . Carbon starvation

\section{Introduction}

Increasing observations of drought-induced forest decline and dieback (Allen et al. 2010) are raising fundamental questions about the ability of trees to cope with intensified heat and drought stress. These questions obtain even more relevance when considering that future climate is expected to be warmer and characterized by more extreme events (IPCC 2013). Trees, being long-living organisms, have developed mechanisms to deal with the natural climatic variability. During periods of prolonged water deficit and heat stress, trees typically aim at reducing water consumption by closing stomata (Chaves et al. 2002). This short-term response, which has a negative influence on carbon assimilation, is usually mitigated by the ability of the tree to store and mobilize previously accumulated carbon compounds as sugars and lipids, thus guaranteeing the maintenance and restoration of fundamental metabolic processes during and after the unfavorable period (McDowell et al. 2008; Wiley and Helliker 2012). However, a long-term increasing frequency and magnitude of unfavorable events as heat and drought might deplete the trees reserves intensifying the sensitivity to drought (McDowell 2011). Thus, tree survival and recovery in 
future harsher climate might also depend on the capacity to store and remobilize available reserves (Sala et al. 2010; McDowell 2011). Despite the awareness of the importance of carbon reserves to overcome stress periods, the way a tree allocates carbon for its functioning (i.e., maintenance, growth defense, ion uptake and transport, reproduction, storage) is poorly understood, and even basic mechanisms such as the control of carbon allocation to storage versus growth are still debated (Korner 2003; Ryan 2011; Sala et al. 2012; Wiley and Helliker 2012).

To unravel the mechanism and temporal dynamics of storage, remobilization and use of carbon in relation to environmental stressors (mostly drought or cold), recent tree physiological research has been mainly focusing on identifying priorities in the allocation of reserves (Sala et al. 2012). Particular focus has been given to the quantification (e.g., Hoch et al. 2003; Galiano et al. 2011; Gruber et al. 2012) and dating (Carbone et al. 2013; Richardson et al. 2013) of stored carbon compounds in stressed versus control trees. However, a major limitation of these tree physiological investigations is the limited observational time-window, which, with few exceptions, cannot supply a long-term perspective (e.g., years or decades) of the dynamics of reserve allocation and use (Ryan 2011; Sala et al. 2012; Wiley and Helliker 2012).

Tree-ring anatomy is an emerging methodological approach based on dendrochronology and quantitative wood anatomy that allows complementing the short-term physiological view by a retrospective tree or stand life-span perspective on plant anatomical and structural adjustments in relation to environmental changes (Fonti and Jansen 2012). Many studies measuring xylem cell characteristics across time series of annual rings have already demonstrated a common signal encoding environmental information (see Fonti et al. 2010 for a review). So far, due to the important role of vessels and tracheids in shaping the hydraulic properties of water uplift from the soil to the leaves (Tyree and Zimmermann 2002), these investigations have mainly focused on the characteristics of the water conducting tissue. Examples of identified associations between water conducting cells and the environmental condition have been found in both hardwood and softwood species across a large array of biomes from tropical (Verheyden et al. 2005), to subtropical (Oladi et al. 2014), Mediterranean (DeSoto et al. 2011; Olano et al. 2013a; Hetzer et al. 2014), temperate (Bryukhanova and Fonti 2013) and boreal (Kirdyanov et al. 2003; Fonti et al. 2013). In contrast, despite the important role of the parenchyma tissue for storage and for regulating physiological processes occurring in the xylem and/or in connection to the phloem (Spicer 2014), only very few studies have investigated its environmental sensitivity (Eckstein and Schweingruber 2009).
Parenchyma is a living tissue in woody plants that is important for the storage of water and carbon compounds (Braun 1970; Gartner 1995). This tissue is the living part of the sapwood and, besides providing defence against pathogens (Hudgins et al. 2006), wounding (Arbellay et al. 2010, 2012), refilling of cavitated conduits (Salleo et al. 2009), and formation of heartwood (Bamber 1976), it plays an important metabolic and biological function also by actively regulating the replenishment, storage and use of carbon reserves and water inside the tree stem. Parenchyma cells in the xylem of conifers are predominantly found in rays, although rays can additionally include tracheids cells at their longitudinal tips (Gartner et al. 2000). Rays provide communication, storage, and radial transport between the xylem (mainly storage and sink), the cambium (sink) and the phloem (source) (Romberger et al. 2004). In conifers, ray parenchyma in the xylem can be considered as one of the main container (the repository) for storing carbon compounds (Spicer 2014) and thus might be of particular interest to retrospectively explore whether changes in ray abundance within the same species or the same individual can reflect trees' (maximal) storage capacity in response to environmental stress (von Arx et al. 2012). Assuming that active storage improves the chances of survival in response to an increased threat of carbon starvation (Wiley and Helliker 2012), we could expect higher ray proportion under increased stressful conditions. However, since (1) increased storage can also be achieved through higher concentrations within the same container and the variation of stored and mobilized carbohydrates during the season (Regier et al. 2010; Simard et al. 2013) might equal those over long-term variations, (2) in absolute term the amount of non-structural carbohydrates in sapwood contains $25-41 \%$ of whole tree reserves (Jacquet et al. 2014) although concentrations in the phloem can be an order of magnitude greater than those in the wood (Gruber et al. 2013); (3), the plasticity of the ray volume might be low due to the longevity of the tissue in the sapwood; it is still unclear if and to which extent short- and long-term environmental variation can affect the volume of the containers within the xylem (Eckstein 2013).

Moreover, since the ray network (size and density) needs to fit tracheid size to provide functional integration (e.g., hydraulic conductivity, freezing tolerance, embolism repair, heartwood formation, see review in Spicer 2014), we would expect a higher density of smaller rays in smaller trees featuring smaller tracheids, which might affect the evaluation of the ecological influence on the ray properties (Lev-Yadun and Aloni 1995). This tapering or widening in the dimension of tracheids along the stem axis and consequently between trees of different size is explained by a different duration the cell spends in the expansion phase (Anfodillo et al. 2013) due to decreasing gradient of auxin 
concentration from leaves to root (Aloni 2014; Uggla et al. 1996).

This study aims at providing a quantification of the variability of the anatomical properties of rays among sites, individuals, and annual rings to verify (1) if ray abundance is linked with the amount of storage as imposed by the environmental conditions, and/or (2) if the changes in ray dimensions and density are associated with changes in other wood tissues. The study area has been explicitly selected at high latitude to highlight tree's carbon economy in a temperature-limited environment to minimize interference with drought responses. By using tree-ring anatomy, we compared several ray characteristics across a gradient of forest productivity in the permafrost region of Central Siberia, and we related the results to tracheid size.

\section{Materials and methods}

\section{Study area and site characteristics}

The study was carried out in the boreal forest of Central Siberia, a relatively harsh environment for tree growth. The study area was located in the proximity of the Tura field station of the VN Sukachev Institute of Forest (Evenkia, Krasnoyarsk region, $\left.64^{\circ} 18^{\prime} \mathrm{N}, 100^{\circ} 11^{\prime} \mathrm{E}\right)$. The climate is continental characterized by extremely cold winter with relatively warm summer. According to the instrumental records of the meteorological station in Tura (1929-2010, $150 \mathrm{~m}$ asl), the mean annual air temperature of the region is $-9.0^{\circ} \mathrm{C}$, with January being the coldest $\left(-35.9^{\circ} \mathrm{C}\right)$ and July the warmest month $\left(16.5^{\circ} \mathrm{C}\right)$. Annual precipitation is $357 \mathrm{~mm}$, with $171 \mathrm{~mm}$ (48\%) falling during the summer (June-August). The region is located in the continuous permafrost zone predominantly covered by Dahurian Larch (Larix gmelinii). This deciduous conifer naturally grows at the thermal limit of forest distribution of the Asian part of Russia where the resources of soil and mineral nutrition are limited (Abaimov and Koropachinskii 1984). In this environment, Larix gmelinii generates massive mono-specific forests. In the region, the growing season for this species is usually very short starting at the second part of May and ending at the beginning of September (Bryukhanova et al. 2013). These harsh growing conditions combined with the needs to mobilize large amount of stored carbon every spring to build new foliage, makes the selected set-up an ideal study case for exploring environmental effects on variability in ray parenchyma traits. In addition, larch wood is characterized by the presence of only uniseriate rays, i.e., stacked cells to form narrow plates just one cell wide and with tracheids at their extremities.

The three sites were selected along a gradient of forest productivity (in terms of the size and height of mature trees, see Table 1), which is mainly determined by the thermal regime of the layer of seasonally thawing soil. The most productive site (High) has been identified on the river bank of the Kochechum River, where due to direct solar radiation and the low thermal insulation of a very thin layer of soil vegetation, the conditions for tree growth are comparably favorable for the region (Kirdyanov et al. 2013). The less productive site (Low) is located about $5 \mathrm{~km}$ away and about $200 \mathrm{~m}$ higher in elevation. The site lies on a north-facing slope $\left(10^{\circ}\right)$ where tree growth is extremely limited by the persistence of permafrost close to the upper soil layers. The third site $(\mathrm{Mid})$ represents an intermediate level of productivity and is located in the riparian zone of a temporary creek close (ca $30 \mathrm{~m}$ away) from the most productive site on the river bank. The differences in site productivity have been verified in terms of radial growth rates. Ring widths of trees from the low productive site $(0.10 \mathrm{~mm})$ were only about $8 \%$ of the ones observed in the most productive site $(1.31 \mathrm{~mm})$ and $13 \%$ of the intermediate one $(0.80 \mathrm{~mm})$.

\section{Sampling and anatomical measurements}

Wood material for stand characterization was collected in 2010 and 2011 from cores (for High and Mid) and discs (for Low) taken at breast height from a total of 68 randomly selected dominant trees distributed among the sites. Each core and disc has been polished with sand paper to perform tree-ring width measurements and cross-dating.

Anatomical measurements have been performed on wood cross-section and tangential section from a selection of trees per site. In total, 20 cross-sections from 20 different trees of about $0.25 \mu \mathrm{m}$ thickness covering the annual rings from 2000 to 2010, and 39 tangential sections for the years 2005 and 2011 were prepared using a sledge microtome. For anatomical measurements, the micro-sections were stained with astra blue and safranin and permanently fixed in Canada balsam following standard dendrochronological procedures (Gärtner and Schweingruber 2013). Stained slides were then photographed through the phototube of a microscope (Olympus BX41, Tokio Japan) with a $40 \times$ magnification using a mounted digital camera (Canon 650D, Tokyo, Japan) to get high-resolution images (0.945 pixels/ $\mu \mathrm{m})$. Subsequently, overlapping (15-25\%) images were stitched using the PTGui v8 software (New House Internet Services BV, The Netherlands). The measurements on the cross-sections were restricted to a 5-mmwide stripe. Measurements on the tangential section were considering square-shaped subset image areas of $2 \times 2 \mathrm{~mm}$. Rays, identified on both section planes (cross and tangential) as single objects of one or more rays but excluding resin ducts, were manually outlined to obtain 
Table 1 Larix gmelinii stand characteristics of the three selected sites in Siberia (mean \pm standard deviation)

\begin{tabular}{llll}
\hline Site productivity & Low & Mid & High \\
\hline Number of trees surveyed & 31 & 18 & 19 \\
Tree height (m) & $6.1 \pm 1.7$ & $9 \pm 1$ & $17 \pm 2$ \\
DBH (cm) & $5.4 \pm 2.1$ & $10 \pm 1$ & $22 \pm 3$ \\
Age at DBH & $\sim 100$ & $\sim 50$ & $\sim 50$ \\
Radial width of the last ten annual rings (mm) & $0.10 \pm 0.05$ & $0.80 \pm 0.43$ & $1.33 \pm 0.81$ \\
Correlation between the full tree-ring width series (Rbt) & 0.60 & 0.58 & 0.65 \\
Depth of soil active layer & 40 & 40 & 160 \\
Moss layer thickness (cm) & 20 & $30-40$ & $1-2$ \\
\hline
\end{tabular}

High high productivity, Mid medium productivity, Low low productivity site, $D B H$ stem diameter at $1.3 \mathrm{~m}$ height, $r b t$ mean correlation between trees anatomical characterization of rays (number, density, height and area). On each section, both cross and tangential, the percentage of ray surface was calculated as the ratio of the total ray area to the wood area considered. Tracheid characterization (tangential width and length in tangential section and lumen area in cross-section) was also measured. Tracheid length has been manually measured on tracheids clearly showing both their ending tips on the images. Lumen area has been measured for earlywood cells only and then we calculated the 75th percentile for a better weighting of cells that have a higher contribution to water conductivity, while measurements on tangential sections were performed on both earlywood and latewood cells. Tracheid measurements on cross-section were performed for all individuals for the years 2005 and 2011 and for five individuals per site for measurements on tangential sections. Cell anatomical measurements were performed on the images of the micro-sections using the image analysis tools ROXAS (von Arx and Dietz 2005; von Arx and Carrer 2014; Fig. 1) and Image-Pro Plus software (Media Cybernetics Inc, USA).

\section{Statistical analysis}

Factors influencing tree-ring growth, ray and tracheid parameters were identified using linear mixed-effect model. The best model was identified by defining the fixed effects of each initial models, and then by selecting the best random structures based on AICc using the maximum likelihood method (Zuur 2009). Tree identity was included as a random factor, while site and year were considered as fixed effects. Each initial model and all the possible subset models were then compared based on ML criterion and AICc to obtain the optimal model. In case several models showed similar AICc values $<2$, these were refitted by the REML method to obtain estimates and significances of factor effects, and the simplest model with significant fixed effects was chosen according to the principle of parsimony (Burnham and Anderson 2002). Homoscedasticity and normality of residuals were checked graphically. Statistical analyses were performed in $\mathrm{R}$ version 3.1.0 (R Development Core Team 2014) including the packages "ImerTest" and "MuMIn".

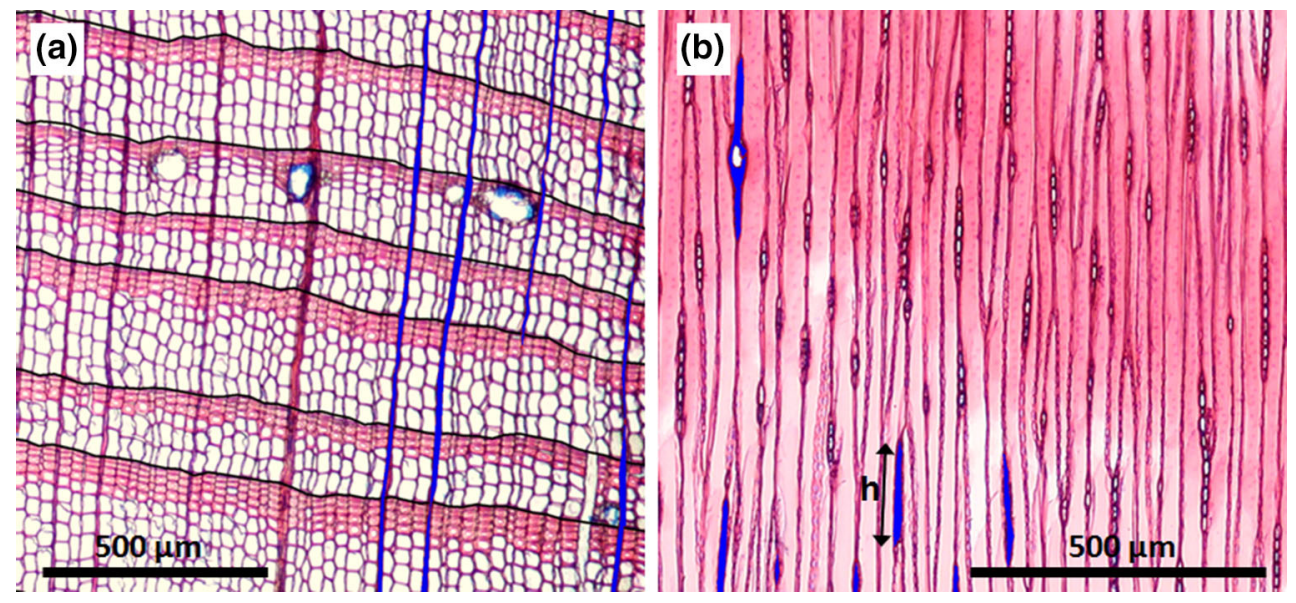

Fig. 1 Example of a cross- and $\mathbf{b}$ tangential micro-sections used for the measurement of ray parenchyma. In both sections, each single ray was outlined manually. The blue objects show some of the outlined rays. Resin ducts in rays were excluded from the ray area measurements 
Partitioning of variance components between and within sites was performed using a generalized linear model (GLM) with two-way ANOVA.

\section{Results}

\section{Variability in ray proportion}

In this study, ray quantification resulted from measurements of an average of $153 \pm 97$ (mean \pm standard error) rays on each cross-section $(n=20)$ and $137 \pm 24$ on each tangential section for each selected sample $(n=39)$ (Table 2). In general, the measurement of ray surface performed on tangential section (range between 2 to $10 \%$ of ray area) was more variable than on the cross-section likely due to a more accurate rays' surface quantification on the tangential section. Although the linear mixed-effect model indicated clearly significant differences in the annual radial growth and cell lumen area among the sites (Fig. 2; Table 3, $p<0.01$ ), the site differences in $\%$ ray surface were found statistically significant $(p<0.05)$ only in the measurements performed on tangential section (Figs. 2, 3). Average ray surface of sites ranged between a minimum of $4.60 \%$ at the low productivity site and $7.12 \%$ at the high productive one (data refer to measurement on tangential sections). However, the full range of ray surface from all tangential sections ranged from a minimum of $3.01 \%$ to a maximum of $11.18 \%$ (Fig. 3), indicating a high inter-tree variability. This result has been confirmed by the quantification of the partitioning of the variance, which has shown that the difference among the sites only little contributed to overall variability ( 7 and $23 \%$ for cross- and tangential section, respectively), whereas the contribution of the within-site variability was considerably larger (62 and $63 \%$, respectively).

Considering the variability in ray surface along the series of tree rings (period 2000-2010), thus considering only the measurements from the cross-sections (Fig. 4), we observed an average coefficient of variation of 10.7, 13.0 and $15.1 \%$ for Low, Mid and High, respectively. The correlation between all site time series of percentage ray surface (Rbt) was 0.00 , and ranged between -0.15 for Low and 0.20 for High, indicating no common signal between and within the sites.

\section{Ray and tracheid anatomical structure}

Earlywood tracheid lumen area of the low productive site was significantly smaller than for the other two sites. On average, the 75 th percentile of the tracheid lumen area was $547 \pm 38 \mu^{2}, 1121 \pm 63 \mu \mathrm{m}^{2}, 965 \pm 59 \mu^{2}$, for Low, Mid and High, respectively (mean \pm standard error, Fig. 2). Similar significant site differences have been provided by the linear mixed-effect model for ray height $(p<0.01)$ and density $(p<0.05)$, as measured on the tangential section (Fig. 3). Average ray height was smaller at the lower site $(133 \pm 1.8 \mu \mathrm{m})$, corresponding to 37 and $45 \%$ of the height observed in the Mid $(212 \pm 2.8 \mu \mathrm{m})$ and High $(242 \pm 2.9 \mu \mathrm{m})$ sites, respectively (Table 2$)$. Site average ray density was $40.1 \pm 1.9 \mathrm{~mm}^{-2}$, $33.3 \pm 1.7 \mathrm{~mm}^{-2}$ and $30.9 \pm 1.1 \mathrm{~mm}^{-2}$, for Low, Mid

Table 2 Number of trees, micro-sections, annual rings and anatomical characteristics measured in both the cross-section and tangential section (mean \pm standard error) of the Larix gmelinii site in Siberia

\begin{tabular}{|c|c|c|c|c|c|c|}
\hline \multirow[t]{2}{*}{ Site } & \multicolumn{3}{|l|}{ Cross-section } & \multicolumn{3}{|c|}{ Tangential section } \\
\hline & Low & Mid & High & Low & Mid & High \\
\hline No. of trees & 5 & 10 & 5 & 5 & 7 & 8 \\
\hline No. of sections & 5 & 10 & 5 & 10 & 14 & 15 \\
\hline Annual rings (years) & 2000-2010 & $2000-2010$ & 2000-2010 & 2005,2011 & 2005,2011 & 2005,2011 \\
\hline Tree-ring width (mm) & $0.09 \pm 0.04$ & $0.76 \pm 0.47$ & $1.32 \pm 0.70$ & $0.08 \pm 0.16$ & $0.54 \pm 0.44$ & $1.31 \pm 0.56$ \\
\hline Total no. of rays & 404 & 1884 & 774 & 1617 & 1714 & 2011 \\
\hline Ray proportion (\%) & $5.70 \pm 0.24$ & $6.78 \pm 0.14$ & $6.44 \pm 0.12$ & $4.60 \pm 0.36$ & $6.24 \pm 0.36$ & $6.64 \pm 0.44$ \\
\hline Single ray area $\left(\mu \mathrm{m}^{2}\right)$ & - & - & - & $1133 \pm 355$ & $1879 \pm 35$ & $2383 \pm 45$ \\
\hline Ray height $(\mu \mathrm{m})$ & - & - & - & $133 \pm 1.76$ & $212 \pm 2.78$ & $242 \pm 2.86$ \\
\hline Ray density $\left(\mathrm{mm}^{-2}\right)$ & - & - & - & $40.1 \pm 1.9$ & $33.3 \pm 1.7$ & $30.9 \pm 1.1$ \\
\hline Cell lumen area $\left(\mu \mathrm{m}^{2}\right)$ & $547 \pm 38$ & $1121 \pm 63$ & $965 \pm 59$ & - & - & - \\
\hline Tracheid tangential width $(\mu \mathrm{m})$ & - & - & - & $28.0 \pm 1.4$ & $30.2 \pm 2.4$ & $30.4 \pm 1.1$ \\
\hline Tracheid length $(\mu \mathrm{m})$ & - & - & - & $2273 \pm 174$ & $2506 \pm 192$ & $2643 \pm 224$ \\
\hline
\end{tabular}

Cell lumen area was measured only for the years with tangential sections and quantified as a $75 \%$ percentile. Tracheid tangential width and length were measured on five individuals per site as means including both early- and latewood cells

High high productivity, Mid medium productivity, Low low productivity site 

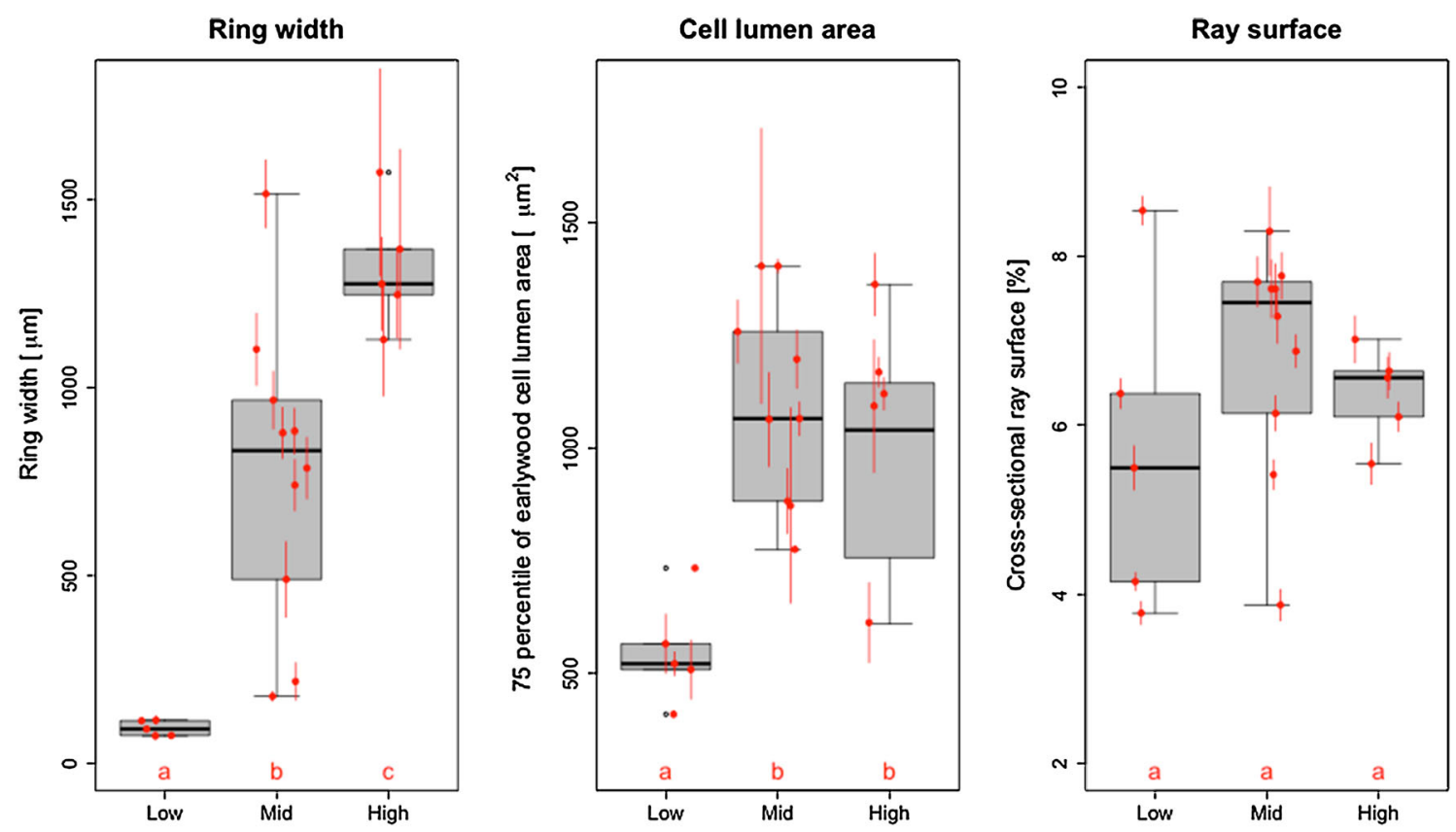

Fig. 2 Summary plot of ring width, cell lumen area and proportion of ray surface as measured on the cross-sections and grouped by site. The box plot indicates the distribution of tree average values; the red points with error bars indicate within-tree values (mean \pm standard error of single annual ring measurements, years 2000-2010 or ring

width and ray surface, and 2005 and 2011 for cell lumen area). High high productivity, Mid medium productivity, Low low productivity. Different letters indicate significant differences at $p<0.05$ based on linear mixed-effect models (for Ring width without considering the Year effect)

Table 3 Results of linear mixed-effect models (estimates \pm SE) of the analyzed anatomical parameters

\begin{tabular}{|c|c|c|c|c|c|c|c|}
\hline Variables & Ring width (mm) & $\begin{array}{l}\text { Cell lumen area } \\
\left(\mu \mathrm{m}^{2}\right)\end{array}$ & $\begin{array}{l}\text { Cross-sectional } \\
\text { ray surface }(\%)\end{array}$ & $\begin{array}{l}\text { Tangential ray } \\
\text { surface }(\%)\end{array}$ & $\begin{array}{l}\text { Ray density } \\
\left(\mathrm{n} \mathrm{mm}^{-2}\right)\end{array}$ & $\begin{array}{l}\text { Ray height } \\
(\mu \mathrm{m})\end{array}$ & $\begin{array}{l}\text { Rays per } \\
\text { tracheid }\end{array}$ \\
\hline Intercept & $11.5 \pm 27.1$ & $-25,611 \pm 17,156$ & $81 \pm 29 * *$ & $4.6 \pm 0.6^{* * *}$ & $40 \pm 2 * * *$ & $137 \pm 14 * * *$ & $2.5 \pm 0.1 * * *$ \\
\hline High & $139.2 \pm 35.2^{* * *}$ & $420 \pm 120 * *$ & - & $2.2 \pm 0.8^{*}$ & $-9 \pm 3 * *$ & $99 \pm 18 * * *$ & - \\
\hline Mid & $2.7 \pm 30.5$ & $562 \pm 125^{* * *}$ & - & $1.6 \pm 0.8$ & $-7 \pm 3^{*}$ & $78 \pm 19 * * *$ & - \\
\hline Low & 0 & 0 & - & 0 & 0 & 0 & - \\
\hline Year & $-0.005 \pm 0.01$ & $13.0 \pm 8.5$ & $-0.04 \pm 0.01 *$ & - & - & - & - \\
\hline High $\times$ year & $-0.068 \pm 0.02 * * *$ & - & - & - & - & - & - \\
\hline Mid $\times$ year & $-0.001 \pm 0.02$ & - & - & - & - & - & - \\
\hline Low $\times$ year & 0 & - & - & - & - & - & - \\
\hline
\end{tabular}

High high productivity, Mid medium productivity, Low low productivity site

Significant relationships at $0.05,0.01$ and 0.001 probability levels are marked with $*$, **, ***, respectively

and High, respectively. There was a positive relationship between ray area and the tracheid area of both measured on tangential sections $(r=0.65, p<0.01)$. Considering the average tangential tracheid surface (by multiplying tracheid length and width, Table 2), the tracheid density (i.e., the number of tracheid per $\mathrm{mm}^{2}$ of tangential section) was 16, 14 and 13, for Low, Mid and High, respectively. Given the measured ray density (Table 2), it results in a ratio of 2.46, 2.42 and 2.58 rays per tracheid for Low, Mid and
High, respectively, with no statistical differences among the sites (Fig. 5, $p>0.05$ ).

\section{Discussion}

Trees growing in contrasting habitats or facing changes in their interaction with the environment are expected to show physiological and structural adjustments to best cope with 

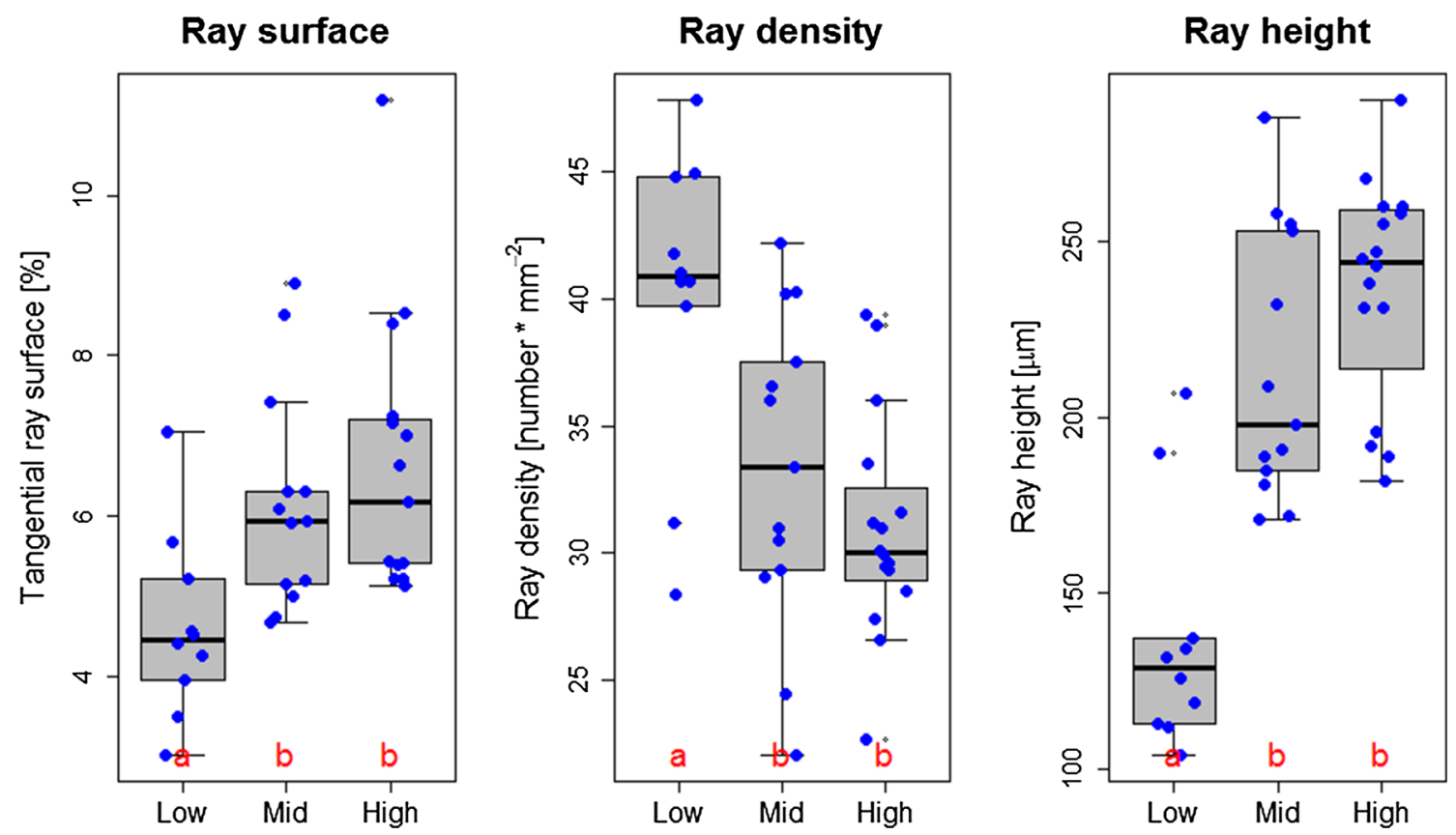

Fig. 3 Summary plot of annual ray surface, ray density and ray height as measured on the tangential sections (years 2005 and 2011 medium productivity, Low low productivity sites. Blue filled dot indicates single section values. Different letters indicate significant for each tree) and grouped by site. High high productivity, Mid differences at $p<0.05$ based on linear mixed-effect models

Fig. 4 Percentage of ray surface as measured along the annual rings (from 2000 to 2010, left plot) and box plot summary grouped by site (right plot). Green high productivity, orange medium productivity, blue low productivity sites. Thick lines (left plot) and filled dot (right plot) indicate year average. Different letters indicate significant differences at $p<0.05$

\section{Ray Surface}

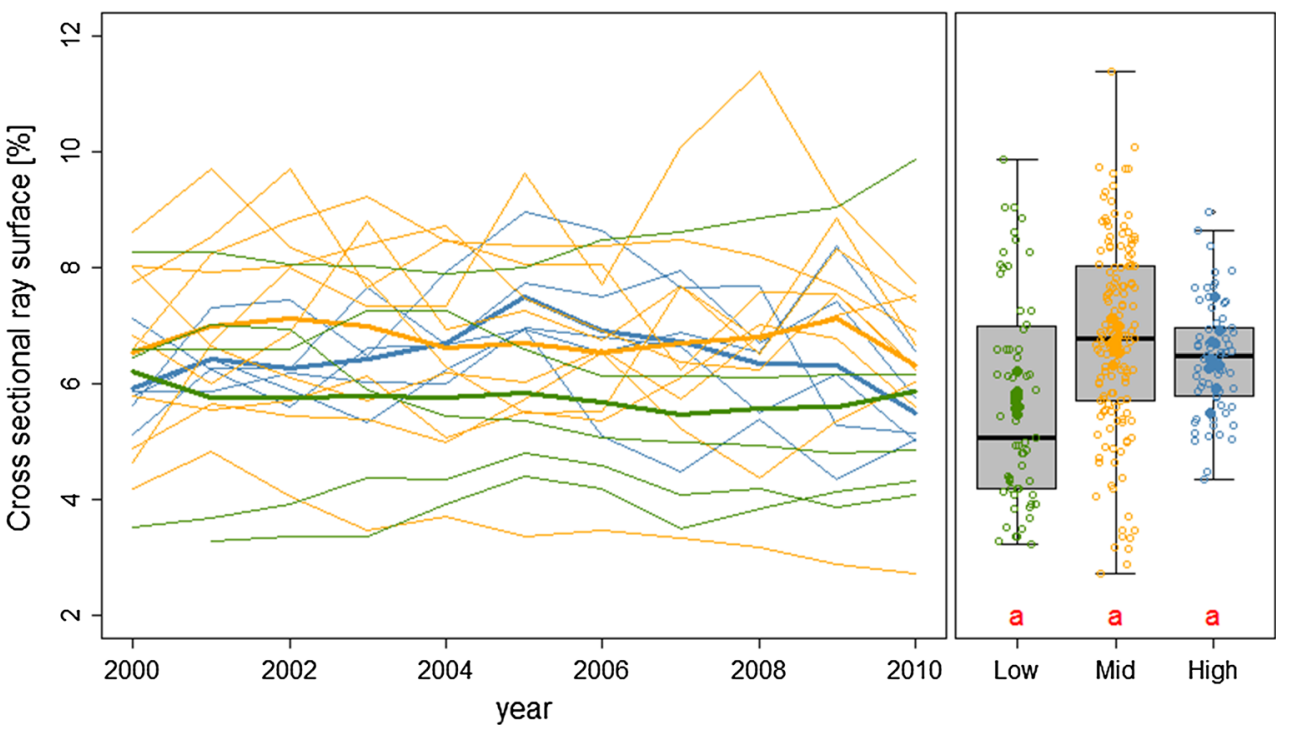

the specific environmental conditions, a pattern that is true among (Baas and Miller 1985; Carlquist 1985), but also within species (Larcher 1995; Meinzer et al. 2011). These adjustments often include changes in wood structure, as wood structure determines essential functions related to tree performance and survival (Gartner 1995). For a deciduous species growing in a cold environment as the ones selected in this study, we expected that available storage space in the stem (i.e., the proportion of ray parenchyma) well reflects the need for storage at the time of ray formation, and that the size and density of rays scale with the size and density of the other surrounding wood tissues (e.g. tracheid). 


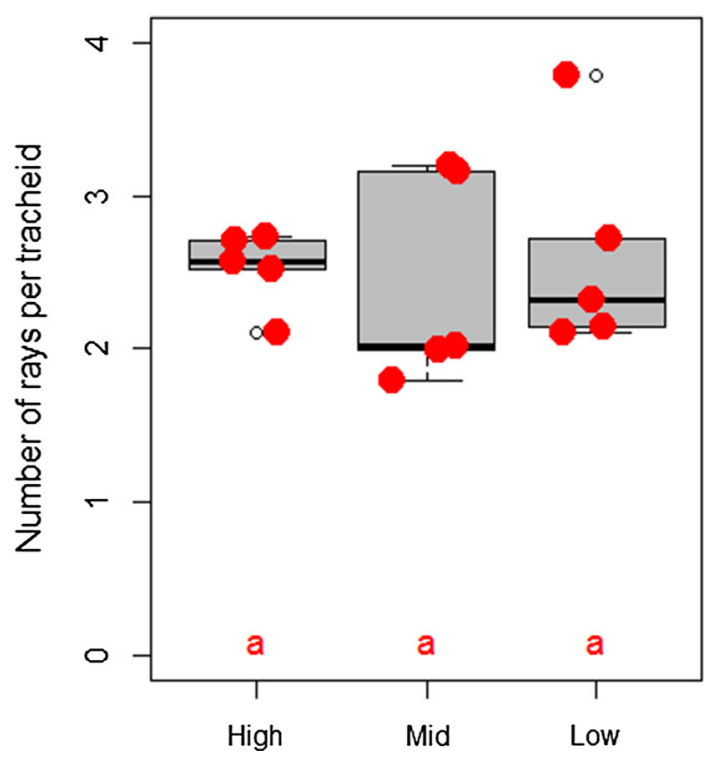

Fig. 5 Summary plot of number of ray per tracheid. High high productivity, Mid medium productivity, Low low productivity sites. Red filled dot indicates individual measurements. Different letters indicate significant differences at $p<0.05$

\section{Variability of ray surface to the environment}

Indications of positive responses of ray abundance have been observed in relation to injuries (Lev-Yadun and Aloni 1992; Arbellay et al. 2010, 2012) confirming that the tissue is capable to immediately and plastically respond to environmental stimuli with locally up to $115 \%$ increases in ray number within few years from the damage (Arbellay et al. 2012). In our study, despite the highly significant reduction in growth $(p<0.01)$, ray abundance between sites was found to be statistically different $(p<0.05)$ only for the measurement on the tangential section. Nevertheless, our results indicate that ray surface tends to increase with increasing productivity with, on average, $13 \%$ (cross-section) and $44 \%$ (tangential section) more abundance in the most productive site compared to the less productive one (see Table 2; Fig. 2 for ray surface measured on crosssection, and Fig. 3 on tangential section). The proportions measured in this study (4.60-6.64\%) match with the lower range of observations performed for various coniferous wood (4.9-11.7 \%, Myer 1922). Even when considering a possible bias in measurement of ray surface due to the fact that rays tended to contain one or two ray tracheids on either side of the ray, the observed declining ray height and density with declining site productivity (Table 2) would leave even less room for ray parenchyma and thus further consolidate our results. Our observations are in agreement with pioneer studies showing similar increase in ray proportion with improved growth conditions due to favorable topography (Myer 1922), or light conditions (Hartig et al.
1894). Our findings showing an increased ray proportion with increasing site productivity indicate, contrarily to our initial hypothesis, for an absence of increased xylem carbon container with increasing stressful conditions and suggest that the xylem ray volume is rather linked to the growth ability of the tree, i.e., related with tree vigor and/or leaf area. However, ray abundance in response to elevated $\mathrm{CO}_{2}$ concentration is contrasting, being negative in 20-year-old Scots pine (Kilpelainen et al. 2007), unaffected in young Scots pine (Ziche and Overdieck 2004), and positive in European beech saplings (Overdieck et al. 2007). Any significant difference in abundance of ray parenchyma has been found between different pine provenances from differently drought-exposed sites in Spain, although with differences in the proportion of ray tracheids, suggesting greater water storage capacity in the trunk of the more drought-exposed trees (Esteban et al. 2010; Martin et al. 2010).

\section{Absence of common year-to-year variability}

The quantifications performed along the series of annual rings (Fig. 4) showed that ray proportion, although with some year-to-year variation (coefficient of variation of sites between 10 and $15 \%)$, has no common signal $(\mathrm{Rbt}<0.2)$. Although some of the year-to-year variation might be caused by the low representativeness of the measurement, which seems to be more unstable when measurements are performed on the cross-section compared to the tangential section, results from a 10-year period indicate an absence of response to any common inter-annual climate variation. Explorations along tree rings of Picea abies have shown similar weak responses with ray height and ray cell number (Wimmer and Grabner 2000), while some characteristics related to the formation of ray parenchyma in Juniperus thurifera from dry environment have been associated with climatic conditions occurring at critical stages of tree-ring formation (Olano et al. 2013b). The absence of coherent year-to-year variability among trees from the same site or between site chronologies could be either obscured by individual variability (especially with respect to our sampling depth) and/or related to the fact that the parenchyma cells within the rays usually stay alive while being part of the sapwood, (up to 30 annual rings in our trees), making rays rather inert to changes in volume.

\section{Other kinds of variability: individual and size related}

Part of the quantified variation in ray abundance was not directly related to the environment. When considering the components of variability, we observed these to be larger between the individuals where ray-abundant trees 
displayed up to three times more ray surface than ray-poor trees from the same site. These differences between individuals might be related to the leaf area as observed by (Gartner et al. 2000) in Pseudotsuga menziesii. In terms of proportion of explained variance, the variability between the sites was responsible for only $8 \%$ (in cross-sections) to $22 \%$ (in tangential sections), while it was $\sim 60 \%$ within the sites. In addition, in our study, we also observed that the lower ray percentage of the less productive site is mainly related to a smaller ray size but with a higher density. Similar increase in ray density and decrease in size have been observed in juvenile compared to the mature earlywood of Pinus halepensis and Pinus pinea (LevYadun 1998). These relationships suggest that the lower ray values (proportion, area and height) are mostly due to a general downscaling related to smaller wood cells rather than from a lower density of rays per surface unit. In fact, wood is a complex biological structure designed to conduct water from the roots to the leaves, to provide mechanical support of the plant body, and to store biochemicals and thus the three main tissue types providing these functions-vascular tissue, fibers and parenchyma-are closely interconnected and their functioning cannot be independent from the properties of the other tissues. Our results support the hypothesis that each single tracheid should share a surface with at least one ray cell (we quantified this ratio to be 2.5 ) to be directly integrated with the phloem and cambium. This would allow the living tissue (rays) to always actively regulate functional processes (i.e., hardwood formation, embolism repair,) in each single tracheid (Spicer 2014). The variability in ray proportion seems therefore to be mainly driven by difference in ray height and only little in ray density, since this feature has to be integrated in the wood structure and thus has to be more conservative.

\section{Conclusions and perspectives}

The quantification of the variability of ray surface among sites, individuals, and annual rings suggest that ray abundance primarily reflects individual-related properties (e.g., size, vitality, social status) rather than the environmental conditions in our study system. First, the size and density of rays have to fit the structure of the other tissues they are connected with to guarantee the necessary functional connectivity. The dimension of an individual ray, as other anatomical features, is linked to the location within the tree and its size, and thus when accounting for size differences, the site effect tend to be annulled while the number of rays per tracheid is kept relatively constant $(\sim 2.5$ in our trees). In addition, our results also indicate that the size of the container in the xylem does not necessarily reflect the amount of stored carbohydrates since we did not observe a higher ray proportion under increased stressful conditions.
This result is thus rather consistent with reports linking more vigorous individuals to greater parenchyma proportion compared to less vigorous ones (Gartner et al. 2000).

Our results are however divergent with regard to the ability to use ray abundance as proxy for environmental conditions. On the one hand, the absence of common response of ray proportion to climatic variability is not promising for high-frequency climatic reconstruction. However, on the other hand, there is part of unexplained variability between individuals and partially between sites that might be associated with the changing balance between carbon supply and demand to the environmental conditions the tree experiences in the long term. Trees in more stressful conditions acquire less carbon but their demands might not decrease with the same amount. The response might also be different depending on the stress factor. For example in a cold environment, a direct inhibition of growth will limit carbon consumption but less assimilation (Korner 2003), while under dry conditions the absence of water would lead to reduced assimilation. These considerations suggest that medium- and low-frequency variation of ray abundance can still provide keys for understanding the dynamic of long-term carbon storage economy of trees (Eckstein 2013; Olano et al. 2013b). In this regard, it would be of particular interest to retrospectively investigate if there are coherent environmental indications explaining the strong inter-tree variability, which might be either related to trees internal factors, such as for example genetic make-up or vigor. Further studies retrospectively quantifying trajectory or ray abundance in living and dead individuals (sensu Hereş et al. 2014) might be helpful to test if, for example, the reduction in ray abundance over a tree's life can be used as an early warning indicator for depleting carbon reserves and/or declining tree vitality. Positive results might supply a complementary tool for a more thorough understanding of the response of trees to global climatic change through retrospective analysis of tree's carbon economy. However, we agree with (Lev-Yadun and Aloni 1995) that tree size and ontogeny have to be taken into account to avoid the ecological hypothesis to just be a sampling artifact. More knowledge of allometric relation and on long-term variation in ray parenchyma over many tree rings is thus welcome (Lei et al. 1996; Meinzer et al. 2011).

Author contribution statement $\mathrm{PF}$ and GvA have designed the study; AK has sampled the wood material; MT has performed the tree-ring width and anatomical survey under the guidance of PF, GvA and $\mathrm{MB}$; and $\mathrm{PF}$ has written the manuscript with the support of all coauthors.

Acknowledgments This work profited from discussions and activities within the framework of the COST Action STReESS (COSTFP1106). The authors are thankful for support from the Swiss State Secretariat for Education for Research and Innovation SERI for the 
C12.0100 grant. MT received a President scholarship from the Ministry of Education in Science of the Russian Federation for a fourmonth stay at WSL in Switzerland to perform measurements and analysis. AK has sampled the wood material and measured tree-ring width (Russian Science Foundation; project 14-14-00295).

Conflict of interest The authors confirm that there is no conflict of interest.

\section{References}

Abaimov AP, Koropachinskii IY (1984) Listvennitsa Gmelina i Kayandera (Gmelin Larch and Cajander Larch), Novosibirsk

Allen CD, Macalady AK, Chenchouni H, Bachelet D, McDowell N, Vennetier M, Kitzberger T, Rigling A, Breshears DD, Hogg EH, Gonzalez P, Fensham R, Zhang Z, Castro J, Demidova N, Lim JH, Allard G, Running SW, Semerci A, Cobb N (2010) A global overview of drought and heat-induced tree mortality reveals emerging climate change risks for forests. For Ecol Manag 259:660-684

Aloni R (2014) Ecophysiological implications of vascular differentiation and plant evolution. Trees Struct Funct. doi:10.1007/ s00468-014-1070-6

Anfodillo T, Petit G, Crivellaro A (2013) Axial conduit widening in woody species: a still neglected anatomical pattern. Iawa $\mathrm{J}$ 34:352-364

Arbellay E, Stoffel M, Bollschweiler M (2010) Wood anatomical analysis of Alnus incana and Betula pendula injured by a debrisflow event. Tree Physiol 30:1290-1298

Arbellay E, Fonti P, Stoffel M (2012) Duration and extension of anatomical changes in wood structure after cambial injury. J Exp Bot 63:3271-3277

Baas P, Miller RB (1985) Functional and ecological wood anatomy some introductory comments. Iawa Bull 6:281-282

Bamber RK (1976) Heartwood, its function and formation. Wood Sci Technol 10:1-8

Braun HJ (1970) Funktionelle Histologie der sekundären Sprossachse. Gebrüder Borntraeger, Berlin

Bryukhanova M, Fonti P (2013) Xylem plasticity allows rapid hydraulic adjustment to annual climatic variability. Trees Struct Funct 27:485-496

Bryukhanova MV, Kirdyanov AV, Prokushkin AS, Silkin PP (2013) Specific features of xylogenesis in Dahurian larch, Larix gmelinii (Rupr.) Rupr., growing on permafrost soils in Middle Siberia. Russ J Ecol 44:361-366

Burnham KP, Anderson DR (2002) Model selection and multimodel inference: a practical information-theoretic approach. Springer, New York

Carbone MS, Czimczik CI, Keenan TF, Murakami PF, Pederson N, Schaberg PG, Xu XM, Richardson AD (2013) Age, allocation and availability of nonstructural carbon in mature red maple trees. New Phytol 200:1145-1155

Carlquist S (1985) Ecological wood anatomy of some southernCalifornia plants. Am J Bot 72:801

Chaves MM, Pereira JS, Maroco J, Rodrigues ML, Ricardo CPP, Osorio ML, Carvalho I, Faria T, Pinheiro C (2002) How plants cope with water stress in the field. Photosynthesis and growth. Ann Bot 89:907-916

DeSoto L, De la Cruz M, Fonti P (2011) Intra-annual patterns of tracheid size in the Mediterranean tree Juniperus thurifera as an indicator of seasonal water stress. Can J Forest Res 41:1280-1294

Eckstein D (2013) 'A new star'-but why just parenchyma for dendroclimatology? New Phytol 198:328-330
Eckstein D, Schweingruber F (2009) Dendrochronologia-a mirror for 25 years of tree-ring research and a sensor for promising topics. Dendrochronologia 27:7-13

Esteban LG, Martin JA, de Palacios P, Fernandez FG, Lopez R (2010) Adaptive anatomy of Pinus halepensis trees from different Mediterranean environments in Spain. Trees Struct Funct 24:19-30

Fonti P, Jansen S (2012) Xylem plasticity in response to climate. New Phytol 195:734-736

Fonti P, von Arx G, Garcia-Gonzalez I, Eilmann B, Sass-Klaassen U, Gartner H, Eckstein D (2010) Studying global change through investigation of the plastic responses of xylem anatomy in tree rings. New Phytol 185:42-53

Fonti P, Bryukhanova MV, Myglan VS, Kirdyanov AV, Naumova OV, Vaganov EA (2013) Temperature-induced responses of xylem structure of Larix sibirica (Pinaceae) from the Russian Altay. Am J Bot 100:1332-1343

Galiano L, Martinez-Vilalta J, Lloret F (2011) Carbon reserves and canopy defoliation determine the recovery of Scots pine $4 \mathrm{yr}$ after a drought episode. New Phytol 190:750-759

Gartner BL (1995) Plant stems physiology and functional morphology. Academic Press, San Diego

Gärtner H, Schweingruber F (2013) Microscopic preparation techniques for plant stem analysis. Remagen

Gartner BL, Baker DC, Spicer R (2000) Distribution and vitality of xylem rays in relation to tree leaf area in Douglas-fir. Iawa $\mathbf{J}$ 21:389-401

Gruber A, Pirkebner D, Florian C, Oberhuber W (2012) No evidence for depletion of carbohydrate pools in Scots pine (Pinus sylvestris L.) under drought stress. Plant Biol 14:142-148

Gruber A, Pirkebner D, Oberhuber W (2013) Seasonal dynamics of mobile carbohydrate pools in phloem and xylem of two alpine timberline conifers. Tree Physiol 33:1076-1083

Hartig R, Somerville W, Ward HM (1894) Text-book of the diseases of trees. Offices of "Country life", London

Hereş AM, Camarero JJ, López BC, Martínez-Vilalta J (2014) Declining hydraulic performances and low carbon investments in tree rings predate Scots pine drought-induced mortality. Trees Struct Funct 28:1737-1750

Hetzer T, Bräuning A, Leuschner H-H (2014) High-resolution climatic analysis of wood formation of Corsican pine from intra-annual tracheid profiles. Trees Struct Funct (in press)

Hoch G, Richter A, Korner C (2003) Non-structural carbon compounds in temperate forest trees. Plant Cell Environ 26:1067-1081

Hudgins JW, Ralph SG, Franceschi VR, Bohlmann J (2006) Ethylene in induced conifer defense: cDNA cloning, protein expression, and cellular and subcellular localization of 1-aminocyclopropane-1-carboxylate oxidase in resin duct and phenolic parenchyma cells. Planta 224:865-877

IPCC (2013) Climate change 2013: the physical science basis. Contribution of Working Group I to the Fifth Assessment Report of the Intergovernmental Panel on Climate Change. Cambridge University Press, Cambridge

Jacquet J-S, Bosc A, O'Grady A, Jactel H (2014) Combined effects of defoliation and water stress on pine growth and non-structural carbohydrates. Tree Physiol 34:367-376

Kilpelainen A, Gerendiain AZ, Luostarinen K, Peltola H, Kellomaki S (2007) Elevated temperature and $\mathrm{CO}_{2}$ concentration effects on xylem anatomy of Scots pine. Tree Physiol 27:1329-1338

Kirdyanov A, Hughes M, Vaganov E, Schweingruber F, Silkin P (2003) The importance of early summer temperature and date of snow melt for tree growth in the Siberian Subarctic. Trees Struct Funct 17:61-69

Kirdyanov AV, Prokushkin AS, Tabakova MA (2013) Tree-ring growth of Gmelin larch under contrasting local conditions in the north of Central Siberia. Dendrochronologia 31:114-119 
Korner C (2003) Carbon limitation in trees. J Ecol 91:4-17

Larcher W (1995) Physiological plant ecology ecophysiology and stress physiology of functional groups. Springer, Berlin

Lei H, Milota MR, Gartner BL (1996) Between- and within-tree variation in the anatomy and specific gravity of wood in Oregon white oak (Quercus garryana Dougl). Iawa J 17:445-461

Lev-Yadun S (1998) The relationship between growth-ring width and ray density and ray height in cell number in the earlywood of Pinus halepensis and Pinus pinea. Iawa J 19:131-139

Lev-Yadun S, Aloni R (1992) The role of wounding and partial girdling in differentiation of vascular rays. Int $\mathrm{J}$ Plant Sci 153:348-357

Lev-Yadun S, Aloni R (1995) Differentiation of the ray system in woody-plants. Bot Rev 61:45-84

Martin JA, Esteban LG, de Palacios P, Fernandez FG (2010) Variation in wood anatomical traits of Pinus sylvestris L. between Spanish regions of provenance. Trees Struct Funct 24:1017-1028

McDowell NG (2011) Mechanisms linking drought, hydraulics, carbon metabolism, and vegetation mortality. Plant Physiol 155:1051-1059

McDowell N, Pockman WT, Allen CD, Breshears DD, Cobb N, Kolb T, Plaut J, Sperry J, West A, Williams DG, Yepez EA (2008) Mechanisms of plant survival and mortality during drought: why do some plants survive while others succumb to drought? New Phytol 178:719-739

Meinzer FC, Lachenbruch B, Dawson TE (2011) Size-and age-related changes in tree structure and function. Springer, Dordrecht

Myer JE (1922) Ray volumes of the commercial wood of the United States and their significance. J Forest 20:337-351

Oladi R, Brauning A, Pourtahmasi K (2014) "Plastic" and "static" behavior of vessel-anatomical features in Oriental beech (Fagus orientalis Lipsky) in view of xylem hydraulic conductivity. Trees Struct Funct 28:493-502

Olano JM, Almeria I, Eugenio M, von Arx G (2013a) Under pressure: how a Mediterranean high-mountain forb coordinates growth and hydraulic xylem anatomy in response to temperature and water constraints. Funct Ecol 27:1295-1303

Olano JM, Arzac A, García-Cervigón AI, von Arx G, Rozas V (2013b) New star on the stage: amount of ray parenchyma in tree rings shows a link to climate. New Phytol 198:486-495

Overdieck D, Ziche D, Bottcher-Jungclaus K (2007) Temperature responses of growth and wood anatomy in European beech saplings grown in different carbon dioxide concentrations. Tree Physiol 27:261-268

R Development Core Team (2014) R: a language and environment for statistical computing

Regier N, Streb S, Zeeman SC, Frey B (2010) Seasonal changes in starch and sugar content of poplar (Populus deltoides $\times$ nigra $\mathrm{cv}$. Dorskamp) and the impact of stem girdling on carbohydrate allocation to roots. Tree Physiol 30:979-987

Richardson AD, Carbone MS, Keenan TF, Czimczik CI, Hollinger DY, Murakami P, Schaberg PG, Xu X (2013) Seasonal dynamics and age of stemwood nonstructural carbohydrates in temperate forest trees. New Phytol 197:850-861

Romberger JA, Hejnowicz Z, Hill JF (2004) Plant structure: function and development: a treatise on anatomy and vegetative development, with special reference to woody plants. Blackburn Press, Caldwell

Ryan MG (2011) Tree responses to drought. Tree Physiol 31:237-239

Sala A, Piper F, Hoch G (2010) Physiological mechanisms of drought-induced tree mortality are far from being resolved. New Phytol 186:274-281

Sala A, Woodruff DR, Meinzer FC (2012) Carbon dynamics in trees: feast or famine? Tree Physiol 32:764-775

Salleo S, Trifilo P, Esposito S, Nardini A, Lo Gullo MA (2009) Starch-to-sugar conversion in wood parenchyma of field-growing Laurus nobilis plants: a component of the signal pathway for embolism repair? Funct Plant Biol 36:815-825

Simard S, Giovannelli A, Treydte K, Traversi ML, King GM, Frank D, Fonti P (2013) Intra-annual dynamics of non-structural carbohydrates in the cambium of mature conifer trees reflects radial growth demands. Tree Physiol 33:913-923

Spicer R (2014) Symplasmic networks in secondary vascular tissues: parenchyma distribution and activity supporting long-distance transport. J Exp Bot 65:1829-1848

Tyree MT, Zimmermann MH (2002) Xylem structure and the ascent of sap. Springer, Berlin

Uggla C, Moritz T, Sandberg G, Sundberg B (1996) Auxin as a positional signal in pattern formation in plants. Proc Natl Acad Sci USA 93:9282-9286

Verheyden A, De Ridder F, Schmitz N, Beeckman H, Koedam N (2005) High-resolution time series of vessel density in Kenyan mangrove trees reveal a link with climate. New Phytol 167:425-435

von Arx G, Carrer M (2014) ROXAS-a new tool to build centurieslong tracheid-lumen chronologies in conifers. Dendrochronologia 32:290-293

von Arx G, Dietz H (2005) Automated image analysis of annual rings in the roots of perennial forbs. Int J Plant Sci 166:723-732

von Arx G, Archer SR, Hughes MK (2012) Long-term functional plasticity in plant hydraulic architecture in response to supplemental moisture. Ann Bot 109:1091-1100

Wiley E, Helliker B (2012) A re-evaluation of carbon storage in trees lends greater support for carbon limitation to growth. New Phytol 195:285-289

Wimmer R, Grabner M (2000) A comparison of tree-ring features in Picea abies as correlated with climate. Iawa J 21:403-416

Ziche D, Overdieck D (2004) $\mathrm{CO}_{2}$ and temperature effects on growth, biomass production, and stem wood anatomy of juvenile Scots pine (Pinus sylvestris L.). J Appl Bot Food Qual 78:120-132

Zuur AF (2009) Mixed effects models and extensions in ecology with R. Springer, New York 